\title{
TINJAUAN KUALITAS AIR PADA MATA AIR "YEH SANA" DI BANJAR GUNAKSA DESA CEMPAGA KECAMATAN BANGLI KABUPATEN BANGLI TAHUN 2017
}

\author{
I Putu Eka Juliantara', I Wayan Suarta Asmara², I Made Bulda Mahayana
}

\begin{abstract}
Water is one of human need, availability and existence of water source should be preserved and protected from pollution. The purpose of this research to know the quality of water from "Yeh Sana" springs. The method of this research is descriptive. The results obtained are the physical parameters temperature 26,50C, TDS $300 \mathrm{mg} /$, turbidity $2 \mathrm{NTU}$, no taste, odorless, colorless, chemical parameters pH 6,5, Nitrite $0.05 \mathrm{mg} / \mathrm{l}$, Nitrate $10 \mathrm{mg} / \mathrm{l}$, iron $0.3 \mathrm{mg} / \mathrm{l}$, hardness $60 \mathrm{mg} / \mathrm{l}$, and bacteriological parameters E. Coli $0 / 100 \mathrm{ml}$ sample and Coliform 2.2/100 ml sample. Observation of water pollutant risk factors in "Yeh Sana" springs. A value of 2.2 from coliform indicates the presence of waste that can contaminate waters from animal and leaves. Concluded the water from "Yeh Sana" springs qualifies the quality of physics, chemical quality and does not qualify microbiological quality. Recommended for the community to cook water before drinking, always keep the springs clean, make a of protection of the springs.
\end{abstract}

Keywords:, springs, water, water quality

\section{Pendahuluan}

Air merupakan salah satu kebutuhan bagi manusia untuk berbagai keperluan rumah tangga, menjaga kesehatan, dan menjaga kelangsungan hidup. Sumber daya air secara geofisik dikatakan melimpah, hanya sebagian kecil saja yang bisa dimanfaatkan secara langsung. Air adalah salah satu kebutuhan vital manusia, sehingga ketersediaannya dan keberadaan sumber-sumber air mestinya dapat dijaga kelestariannya dan terhindar dari pencemaran (1).

Sumber air bersih secara umum terdiri dari tiga sumber, yakni air permukaan, air tanah dan mata air. Ada yang menyebutkan dan memanfaatkan air hujan sebagai sumber air bersih. Mata air adalah air tanah yang ke luar dengan sendirinya ke permukaan tanah (1).

Mata air adalah sumber air yang muncul dengan sendirinya ke permukaan dari dalam tanah melalui patahan dala tanah sehingga muncul ke permukaan. Mata air yang berasal dari air tanah dalam, hampir tidak terpengaruh oleh musim dan kualitasnya sama dengan keadaan air tanah dalam itu sendiri (2).

Air Mata air "Yeh Sana" dijadikan salah satu andalan untuk memenuhi kebutuhan sehari-hari seperti memasak, minum, mandi dan mencuci. Observasi awal penulis melakukan pengukuran debit air sebesar 4,64 liter/detik.

Kondisi saat ini juga di perparah dengan rumah penduduk yang sudah semakin banyak berdiri disekitar lokasi mata air, sehingga perilaku manusia seperti membuang sampah sembarang dan memelihara binatang peliharaan dekat dengan sumber mata air yang nantinya akan mempengaruhi

1 Mahasiswa Jurusan Kesehatan Lingkungan Poltekkes Denpasar

2,3 Dosen Jurusan Kesehatan Lingkungan Poltekkes Denpasar 
kualitas air tersebut. Lokasi Mata air "Yeh sana" dekat dengan sawah yang berpotensi mencemari mata air. Hal tersebut di kawatirkan karena aktivitas dari petani dalam bertani menggunakan pupuk ataupun pestisida.

Untuk mengetahui kualitas air di Mata air "Yeh Sana" maka penulis melakukan penelitian tentang "Kualitas Air Pada Mata Air "Yeh Sana" di Banjar Gunaksa. Tujuan penelitian ini untuk mengetahui kualitas air pada mata air "Yeh Sana" di Br. Gunaksa seperti : (1) Untuk mengetahui kualitas fisika air di mata air "Yeh Sana", (2) Untuk mengetahui kualitas kimia air di mata air "Yeh Sana", (3) Untuk mengetahui kualitas mikrobiologi air di mata air "Yeh Sana", (4) Untuk mengetahui faktor resiko pencemar air di mata air "Yeh Sana".

\section{Metode}

Jenis penelitian yang digunakan adalah jenis penelitian deskriptif yaitu menggambarkan objek penelitian pada saat penelitian berlangsung berdasarkan fakta-fakta sebagaimana adanya. Penelitian ini dilaksanakan pada bulan April - Juni tahun 2017. Pengambilan sampel air di mata air "Yeh Sana" untuk pemeriksaan di laboratorium mengenai kualitas airnya. Untuk mengetahui faktor resiko pencemar airnya akan dilakukan observasi di lapangan dengan menggunakan lembar observasi. Hasil pengukuran kualitas air akan di bandingkan dengan baku mutu atau standar pada Permenkes RI Nomor 492/MENKES/PER/IV/2010 Tentang Persyaratan Kualitas Air Minum.

\section{Hasil dan Pembahasan}

Penelitian dilakukan di sumber mata air "Yeh Sana" yang terletak di Banjar Gunaksa, Desa Cempaga, Kecamatan Bangli, Kabupaten Bangli. Mata air "Yeh Sana" keluar dari tanah dengan jumlah satu titik sumber air dengan keadaan mata air terbuka tanpa bangunan perlindungan. Air dari Mata air "Yeh Sana" dialirkan melalui 5 (lima) batang pipa PVC yang sehari harinya di ambil dan dimanfaatkan oleh warga setempat.

\section{Kualitas kimia air Mata air "Yeh Sana" \\ Pemeriksaan kualitas fisika air di Mata air "Yeh Sana" menggunakan dua cara yaitu pemeriksaan di lapangan serta pemeriksaan di laboratorium dan mendapatkan hasil sebagai berikut :}


Tabel 1

Hasil Pemerikasaan Kualitas Fisika Air di Mata Air "Yeh Sana"

\begin{tabular}{|c|l|c|c|c|c|}
\hline No & Parameter & Satuan & $\begin{array}{c}\text { Kadar maksimum } \\
\text { yang diperbolehkan }\end{array}$ & Hasil & Ket \\
\hline a. Pemeriksaan Lapangan & $\begin{array}{c}\text { Memenuhi } \\
\text { syarat }\end{array}$ \\
\hline 1 & Suhu & ${ }^{0} \mathrm{C}$ & Suhu udara $\pm 3^{0} \mathrm{C}$ & 26,5 & $\begin{array}{c}\text { Memenuhi } \\
\text { syarat }\end{array}$ \\
\hline 2 & Rasa & - & Tidak berasa & Tidak berasa & $\begin{array}{c}\text { Memenuhi } \\
\text { syarat }\end{array}$ \\
\hline 3 & Bau & - & Tidak berbau & Tidak berbau & $\begin{array}{c}\text { Memenuhi } \\
\text { syarat }\end{array}$ \\
\hline 4 & Warna & - & Tidak berwarna & $\begin{array}{c}\text { Tidak } \\
\text { berwarna }\end{array}$ & $\begin{array}{c}\text { Memenuhi } \\
\text { syarat }\end{array}$ \\
\hline b. Pemeriksaan Laboratorium & mg/l & 500 & 300 & $\begin{array}{c}\text { Memenuhi } \\
\text { syarat }\end{array}$ \\
\hline 1 & TDS & NTU & 5 & 2 & \\
\hline 2 & Kekeruhan & NTU & & & \\
\hline
\end{tabular}

\section{Suhu}

Pengukuran suhu di lapangan maka didapatkan nilai suhu sebesar $26,5^{\circ} \mathrm{C}$. Menurut teori Siregar (3) suhu sebaiknya sejuk atau tidak panas terutama agar tidak terjadi pelarutan zat kimia yang ada pada air yang dapat membahayakan kesehatan. Kenaikan akan suhu menyebabkan penurunan oksigen terlarut, serta pada suhu tinggi zat beracun sangat aktif sehingga berbahaya bagi kesehatan.

\section{Rasa, Bau dan Warna}

Pemeriksaan bau, rasa dan warna di lapangan didapatkan hasil yaitu air dari Mata air "Yeh Sana" tidak berasa, tidak berbau dan tidak berwarna. Menurut teori Siregar (3) rasa, bau dan warna biasanya terjadi secara bersama dan biasanya di sebabkan oleh adanya bahan-bahan organic yang membusuk, tipe-tipe tertentu organisme mikroskopik, serta persenyawaan kimia.

TDS (Total Dissolved Solids)
Hasil pemeriksaan TDS di Laboratorium Jurusan Kesehatan Lingkungan di dapatkan hasil 300 $\mathrm{mg} / \mathrm{l}$. Zat padat terlarut (TDS) merupakan zat padat yang lolos filter pada analisis zat padat tersuspensi, sehingga analisis zat padat terlarut merupakan kelanjutan analisis zat padat tersuspensi (4).

\section{Kekeruhan}

Pemeriksaan kekeruhan di dapatkan hasil 2 NTU. Air dikatakan keruh apabila air tersebut mengandung begitu banyak partikel bahan yang tersuspensi. Penyebab kekeruhan ini meliputi lumpur, bahan-bahan organik yang tersebar dari partikel-partikel kecil yang tersuspensi.

Kualitas kimia air Mata air "Yeh Sana"

Pemeriksaan kualitas kimia air di Mata air "Yeh Sana" menggunakan dua cara yaitu pemeriksaan di lapangan serta pemeriksaan di laboratorium dan mendapatkan hasil sebagai berikut : 
Tabel 2

Hasil Pemerikasaan Kualitas Kimia Air di Mata Air "Yeh Sana"

\begin{tabular}{|l|l|c|c|c|c|}
\hline No & Parameter & Satuan & $\begin{array}{c}\text { Kadar maksimum } \\
\text { yang diperbolehkan }\end{array}$ & Hasil & Ket \\
\hline \begin{tabular}{|l|c|c|c|c|}
\hline a. Pemeriksaan Lapangan \\
\hline
\end{tabular} $\mathrm{pH}$ & - & $6,5-8,5$ & 6,5 & $\begin{array}{c}\text { Memenuhi } \\
\text { syarat }\end{array}$ \\
\hline b. Pemeriksaan Laboratorium \\
\hline 1 & Nitrit $\left(\mathrm{NO}_{2}\right)$ & $\mathrm{mg} / \mathrm{l}$ & 3 & 0,05 & $\begin{array}{c}\text { Memenuhi } \\
\text { syarat }\end{array}$ \\
\hline 2 & Nitrat $\left(\mathrm{NO}_{3}\right)$ & $\mathrm{mg} / \mathrm{l}$ & 50 & 10 & $\begin{array}{c}\text { Memenuhi } \\
\text { syarat }\end{array}$ \\
\hline 3 & Besi(Fe) & $\mathrm{mg} / \mathrm{l}$ & 0,3 & 0,3 & $\begin{array}{c}\text { Memenuhi } \\
\text { syarat }\end{array}$ \\
\hline 4 & Kesadahan & $\mathrm{mg} / \mathrm{l}$ & 500 & 60 & $\begin{array}{c}\text { Memenuhi } \\
\text { syarat }\end{array}$ \\
\hline
\end{tabular}

\section{pH (Derajat Keasaman)}

Pengukuran $\mathrm{pH}$ di lapangan maka didapatkan nilai $\mathrm{pH}$ sebesar 6,5. Menurut teori yang dikemukakan Sanropie dalam Aryana (5) menyatakan bahwa rendah atau tingginya $\mathrm{pH}$ dipengaruhi oleh pemukiman penduduk, tegalan, kandang sapi dan kandang babi yang menghasilkan limbah padat (sampah/bahan organic) dan limbah cair yang dapat meresap kesumber mata air yang berada di bawahnya.

\section{Nitrit $\left(\mathrm{NO}_{2}\right)$}

Pemeriksaan Nitrit $\left(\mathrm{NO}_{2}\right)$ di Laboratorium Jurusan Kesehatan Lingkungan di dapatkan hasil 0,05 $\mathrm{mg} / \mathrm{l}$. Kandugan nitrit pada perairan alami mengandung Nitrit sekitar 0,001 mg/l. Keberadaan Nitrit menggambarkan berlangsungnya proses biologis perombakan bahan organic yang memiliki kadar oksigen terlarut yang rendah. Tinggi rendahnya nilai kandungan nitrit ini dapat disebabkan oleh faktor-faktor seperti kandungan oksigen terlarut, suhu, $\mathrm{pH}$, Selain itu Nitrit juga bersifat racun karena dapat bereaksi dengan hemoglobin dalam darah, sehingga darah tidak dapat mengangkut oksigen (6).

\section{Nitrat (NO3)}

Pemeriksaan Nitrat $\left(\mathrm{NO}_{3}\right)$ di Laboratorium Jurusan Kesehatan Lingkungan di dapatkan hasil $10 \mathrm{mg} / \mathrm{l}$. Nitrat adalah kontaminan didalam air minum yang umumnya berkaitan erat dengan kegiatan pertanian.Nitrat dalam air tanah berasal terutama dari penggunaan pupuk.

\section{Besi (Fe)}

Pemeriksaan besi $(\mathrm{Fe})$ di Laboratorium Jurusan Kesehatan Lingkungan di dapatkan hasil 0,3 mg/l. Menurut Teori Sanropie dalam Aryana (5) menyatakan bahwa tinggi rendahnya kadar $\mathrm{Fe}$ dipengaruhi oleh pemukiman penduduk, tempat pembuangan sampah dan persawahan.

\section{Kesadahan}

Pemeriksaan kesadahan di Laboratorium Jurusan Kesehatan Lingkungan di dapatkan hasil $60 \mathrm{mg} / \mathrm{l}$. Sifat kesadahan seringkali ditemukan pada air yang menjadi sumber baku air bersih yang berasal dari air tanah atau daerah yang tanahnya mengandung deposit garam mineral dan kapur. 
Kualitas mikrobiologi air Mata air "Yeh Sana"

Pemeriksaan

mikrobiologi air di Mata air "Yeh
Sana" menggunakan cara pemeriksaan di laboratorium dan mendapatkan hasil sebagai berikut :

Tabel 3

Hasil Pemerikasaan Kualitas Mikrobiologi Air di Mata Air "Yeh Sana"

\begin{tabular}{|c|c|c|c|c|c|}
\hline No & Parameter & Satuan & $\begin{array}{c}\text { Kadar maksimum } \\
\text { yang diperbolehkan }\end{array}$ & Hasil & Ket \\
\hline \multicolumn{7}{|c|}{ a. Pemeriksaan Laboratorium } & 0 & 0 & $\begin{array}{c}\text { Memenuhi } \\
\text { syarat }\end{array}$ \\
\hline 1 & E Coli & $\begin{array}{c}\text { Per } 100 \mathrm{ml} \\
\text { sampel }\end{array}$ & 0 & 2.2 & $\begin{array}{c}\text { Tidak } \\
\text { memenuhi } \\
\text { syarat }\end{array}$ \\
\hline 2 & Coliform & $\begin{array}{c}\text { Per } 100 \mathrm{ml} \\
\text { sampel }\end{array}$ & 0 &
\end{tabular}

\section{Escerichia Coli}

Pemeriksaan E.Coli di Laboratorium Jurusan Kesehatan Lingkungan di dapatkan hasil 0 per $100 \mathrm{ml}$ sampel. Menurut Sugma (6) Sumber-sumber air di alam pada umumnya mengandung bakteri, baik air angkasa, air permukaan, maupun air tanah. Jumlah dan jenis bakteri berbeda sesuai dengan tempat dan kondisi yang mempengaruhinya. Oleh karena itu air yang dikonsumsi untuk keperluan sehari-hari harus bebas dari bakteri patogen. Menurut Chandra (7) E.Coli sudah lama diketahui sebagai indikator adanya pencemaran tinja manusia pada minuman ataupun makanan.

\section{Coliform}

Pemeriksaan Coliform di Laboratorium Jurusan Kesehatan Lingkungan di dapatkan hasil 2,2 per $100 \mathrm{ml}$ sampel. Bakteri Coliform tergolong ke dalam famili Enterobacteriaceae bersifat Gram negatif batang,memfermentasi fakultatif anaerob dan suhu optimumnya $37^{0} \mathrm{C}(8)$.

\section{Faktor resiko pencemar air Mata air "Yeh Sana"}

Berdasarkan hasil penilaian lembar observasi faktor resiko pencemar air di Mata air "Yeh Sana" diperoleh hasil bahwa 7 item penilaian yang memenuhi syarat dan 5 item penilaian yang tidak memenuhi syarat. Jadi hasil dari observasi lapangan mengenai faktor resiko pencemar air di Mata air "Yeh Sana" adalah cukup memenuhi syarat dengan nilai 7 .

Melalui observasi secara langsung keadaan Mata air "Yeh Sana", mata air tersebut dapat dikatakan cukup memenuhi syarat. Mata air ini memiliki air yang jernih, tidak bewarna, tidak berasa dan tidak menimbulkan bau tak sedap. Di sekitar mata air tidak terdapat genangan air yang memungkinkan adanya aktivitas mikro organisme phatogen. Di sekitar mata air juga tidak terdapat TPS/TPA, industri serta 10 meter dari mata air tidak terdapat septic tank. Resiko pencemar air di Mata air "Yeh Sana" disebabkan oleh adanya sawah dan pemukiman di sekitar mata air. Karena tidak adanya bangunan perlindungan mata air di Mata air "Yeh Sana", maka

1 Mahasiswa Jurusan Kesehatan Lingkungan Poltekkes Denpasar

2,3 Dosen Jurusan Kesehatan Lingkungan Poltekkes Denpasar 
resiko tercemarnya air dari mata air tersebut sangat tinggi. Terdapatnya pepohonan di atas mata air sangat rentan menjadi habitat binatang seperti burung. Selain guguran daun yang akan mengotori mata air, kotoran burung juga akan ikut mengotori mata air dan mengkontaminasi air dari mata air tersebut. Kebersihan mata air sangat penting dijaga agar resiko dari pencemaran bisa di tanggulangi.

\section{Simpulan}

Adapun simpulan dari penelitian yang telah dilakukan di Mata air "Yeh Sana" : (1) Kualitas fisika air Mata air "Yeh Sana" yaitu suhu $26,5^{\circ} \mathrm{C}$, TDS 300 mg/l, kekeruhan 2 NTU, air tidak berasa, tidak berbau serta tidak bewarna, dan memenuhi syarat secara kualitas fisika, (2) Kualitas kimia air Mata air "Yeh Sana" yaitu pH 6,5, Nitrit $\left(\mathrm{NO}_{2}\right)$ 0,05 mg/l, Nitrat $\left(\mathrm{NO}_{3}\right) 10$ $\mathrm{mg} / \mathrm{l}$, Besi (Fe) 0,3 mg/l, Kesadahan $60 \mathrm{mg} / \mathrm{l}$, dan memenuhi syarat secara kualitas kimia, (3) Kualitas air mikrobiologi Mata air "Yeh Sana" yaitu E Coli 0 per $100 \mathrm{ml}$ sampel, Coliform 2,2 per $100 \mathrm{ml}$ sampel dan tidak memenuhi syarat secara kualitas mikrobiologi, (4) Observasi faktor resiko pencemar air di Mata air "Yeh Sana" termasuk kategori cukup memenuhi syarat dari lingkungan fisik.

\section{Saran}

(1) Untuk masyarakat yang memanfaatkan air dari Mata air "Yeh Sana" sebagai air minum agar dimasak sampai mendidih.(2) untuk petugas Puskesmas Bangli Utara yang mewilayahi kelurahan Cempaga agar meningkatkan pengawasan kualitas air bersih.

\section{Daftar Pustaka}

1. Oviantari. Analisis Indek Kualitas Air Pada Mata Air Tlebusan Baluan, Pancoran Camplung, Dan Pancoran Padukuhan Di Banjar Cau, Tabanan. In 2011.

2. Arthana. Studi Kualitas Air Beberapa Mata Air di Sekitar Bedugul. In: Universitas Udayana. 2004.

3. Siregar. Analisis Kualitas Fisik, Biologi, Dan Kimia Pada Air Minum Dalam Kemasan Berbagai Merk Yang Dijual Di Kota Medan Tahun 2012. In 2012.

4. Marendy. Analisis Kandungan TSS (Total Suspended Solid) dan TDS (Total Dissolved Solid) di Perairan Pulau Pahawang, Lampung. In 2013.

5. Aryana. Analisis Kualitas Air Dan Lingkungan Fisik Pada Perlindungan Mata Air Di Wilayah Kerja Puskesmas Tabanan I Kabupaten Tabanan. In: Universitas Udayana. 2010.

6. Sugma. Analisis Nitrit (NO2) Dalam Air. In 2014.

7. Chandra. Pengantar Kesehatan Lingkungan. In: EGC Jakarta. 2007.

8. Suarjana. Kualitas Air Minum Ternak Ayam Petelur di Desa Piling Kecamatan Penebel Kabupaten Tabanan di Tinjau dari Jumlah Bakteri Coliform. In 2009. 